Check for updates

Cite this: RSC Adv., 2021, 11, 35525

\title{
Membrane technologies in toilet urine treatment for toilet urine resource utilization: a review $\uparrow$
}

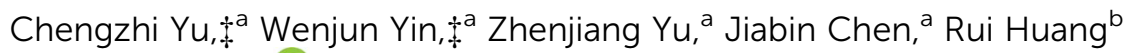 \\ and Xuefei Zhou (D)*ac
}

\begin{abstract}
Membrane technologies have broad potential in methods for separating, collecting, storing, and utilizing urine collected from toilets. Recovering urine from toilets for resource utilization instead of treating it in a sewage treatment plant not only reduces extra energy consumption for the degradation of $\mathrm{N}$ and $\mathrm{P}$ but also saves energy in chemical fertilizer production, which will contribute to carbon emission reduction of $12.19-17.82 \mathrm{~kg} \mathrm{kgN}_{\mathrm{N}}^{-1}$ in terms of $\mathrm{N}$ alone. Due to its high efficiency in terms of volume reduction, water recycling, nutrient recovery, and pollutant removal, membrane technology is a promising technology for resource utilization from urine collected from toilets. In this review, we divide membrane technologies for resource utilization from urine collected from toilets into four categories based on the driving force: external pressure-driven membrane technology, vapor pressure-driven membrane technology, chemical potential-driven membrane technology, and electric field-driven membrane technology. These technologies influence factors such as: recovery targets and mechanisms, reaction condition optimization, and process efficiency, and these are all discussed in this review. Finally, a toilet with source-separation is suggested. In the future, membrane technology research should focus on the practical application of source-separation toilets, membrane fouling prevention, and energy consumption evaluation. This review may provide theoretical support for the resource utilization of urine collected from toilets that is based on membrane technology.
\end{abstract}

Received 31st July 2021

Accepted 12th October 2021

DOI: 10.1039/d1ra05816a

rsc.li/rsc-advances process is $45 \mathrm{MJ} \mathrm{kg}^{-1}$ and $49 \mathrm{MJ} \mathrm{kg}^{-1}$, respectively. ${ }^{2}$ Although an anammox-based process could reduce oxygen demand by up to $63 \%,{ }^{3}$ low-cost $\mathrm{P}$ removal processes have not yet been found. However, in light of the dire situation of fertilizer depletion, $\mathrm{N}$ and $\mathrm{P}$ in human urine should be reclassified as resources. According to the Food and Agriculture Organization of the United Nations (FAO), ${ }^{4}$ the demand of N, P and K were 111.575, 38.372 , and 33.149 tonnes, respectively, in 2016, whereas the demand increased by $1.4-1.5 \%$ every year. By 2020 , the requirement of $\mathrm{N}, \mathrm{P}$ and $\mathrm{K}$ may rise to $118.763,42.133$ and 37.042 tonnes, respectively. Currently, the $\mathrm{N}$ fertilizers are mainly synthesized via the Haber-Bosch process, ${ }^{5}$ and the $\mathrm{P}, \mathrm{K}$ fertilizers are mostly produced from the exploitation of phosphate rock and potassium minerals. ${ }^{6}$ However, the energy consumption of the Haber-Bosch process is $8.9-19.3 \mathrm{~kW} \mathrm{~h}$ $\mathrm{kg}_{\mathrm{N}}{ }^{-1}$, which accounts for about $1-2 \%$ of the world's energy use. ${ }^{7}$ On the one hand, phosphate rock and potassium minerals are limited in nature; on the other hand, fertilizer processing introduces heavy metals into the environment. ${ }^{8}$ Therefore, sustainable, heavy metal-free sources of fertilizer will be indispensable in the future. Human urine is rich in $\mathrm{N}, \mathrm{P}$, and $\mathrm{K}$. In addition to $\mathrm{N}, \mathrm{P}$ and $\mathrm{K}$, the secondary nutrients found in human urine such as sulfur, calcium, magnesium and micronutrients such as boron, copper, and zinc are all that plants need to grow. ${ }^{9}$ The heavy metal content in urine is far below than found 
in chemical fertilizers. ${ }^{10}$ To sum up, there are several benefits of separately collecting human urine from toilets and utilizing it as a resource: (1) producing fertilizer with a low heavy metal content, (2) saving energy consumption in sewage treatment and $\mathrm{N}$ fertilizer production, (3) solving the phosphate rock and potassium mineral deficiency problem.

According to the $\mathrm{CO}_{2}$ emission coefficients of electricity and fossil fuels, ${ }^{\mathbf{1 1}}$ carbon reduction from recycling $\mathrm{N}$ before treatment in the WWTP and using it for $\mathrm{N}$ fertilizer production is about $12.19-17.82 \mathrm{~kg} \mathrm{~kg}_{\mathrm{N}}{ }^{-1}$.

Source-separation technology provides a new idea to replace the treatment of human urine in a WWTP and further realize the resource utilization. Separated urine has a higher resource value than mixed manure and urine. Urine source-separation, in other words, urine-diversion, was first proposed in 1996, ${ }^{12}$ after which research on urine-derived fertilizer, ${ }^{13}$ urine diversion systems installation and operation, ${ }^{\mathbf{1 4}}$ microbiological and physical-chemical process for urine treatment, ${ }^{15}$ user attitudes towards urine diversion ${ }^{\mathbf{1 6}}$ commenced. In recent years, sourceseparation toilets have developed gradually all over the world, ${ }^{17}$ including Sweden, South Africa and so on. However, source-separated urine was commonly diluted 5-20 times during source-separation due to water flushing. ${ }^{18}$ Because of the large volume, transportation costs would be extremely high, so in-person use is advised. If transportation is unavoidable, a volume reduction of $80 \%$ is recommended. ${ }^{19}$

Maurer et $a .^{20}$ proposed several objectives for sourceseparated urine treatment: disinfection, stabilization, volume reduction, P-recovery, N-recovery, organic compounds' removal and micropollutant handling. There have been many technologies for source-separated urine resource utilization, such as the struvite method, ${ }^{21}$ an adsorption method, ${ }^{22}$ ion exchange, ${ }^{23}$ freezing-thawing, ${ }^{24}$ drying, ${ }^{25}$ and bio-electrochemical technologies. ${ }^{\mathbf{2 6 , 2 7}}$ Membrane technologies, in comparison to other urine resource utilization technologies, can address a broader range of objectives. Membrane technologies, for example, provide unrivalled benefits in urine treatment, particularly in urine reduction and water recovery. Furthermore, membrane technologies are crucial in $\mathrm{N}$ and $\mathrm{P}$ recovery, organic compound removal and micropollutant treatment. As far as is known, reviews on urine recycling by membrane technologies are still limited.

Herein, the properties of urine collected from toilets are summarized, based on an extensive literature review to provide a comprehensive understanding of human urine composition, utilization value and chemical properties, so that the selection of a membrane process according to different recovery purposes and the nature of the human urine is clearer. More importantly, membrane technology treatments for urine collected from toilets are classified as external pressure-driven membrane technology, vapor pressure-driven membrane technology, chemical potential-driven membrane technology, and electric field-driven membrane technology, according to the driving force, as shown in Fig. 1. These membrane technologies' process applications and influencing factors, including combination processes, are described. The research hotspots of membrane technology are summarized and the directions of membrane technology development have been explored. These studies provide preliminary theoretical support for the flexible selection of membrane processes and the establishment of a source-separation toilet system incorporating membrane technology.

\section{Human urine properties}

\subsection{Yield and composition}

Urine is a sterile, with amber colored fluid, excreted by the kidney filtration process. ${ }^{28}$ The daily urine output of an adult is

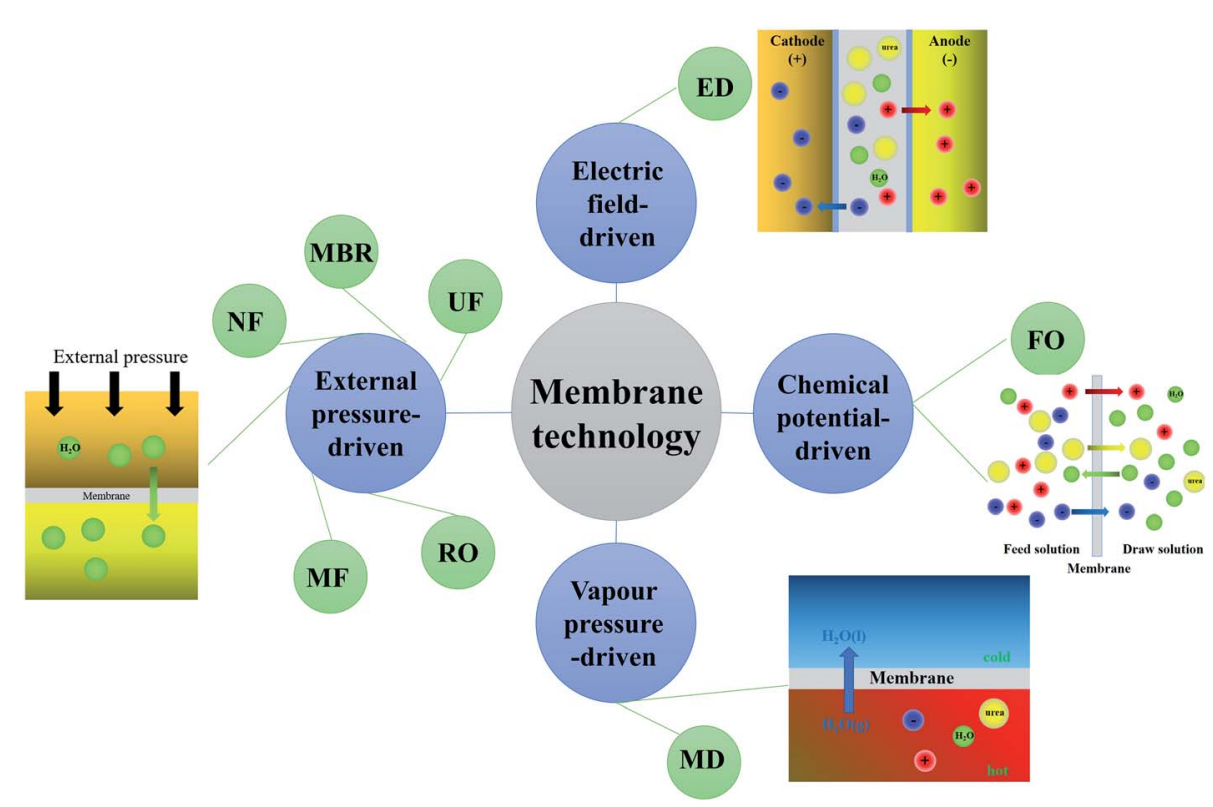

Fig. 1 Membrane technologies classified according to the driving force (MBR - membrane bioreactor, NF - nanofiltration, MF microfiltration, UF - ultrafiltration, RO - reverse osmosis, FO - forward osmosis, ED - electrodialysis, and MD - membrane distillation). 
Table 1 The composition and properties of human urine

\begin{tabular}{|c|c|c|c|}
\hline Component & Concentration & Component & Concentration \\
\hline $\mathrm{pH}$ & $4.88-9.3$ & $\operatorname{Mg}\left(\mathrm{mg} \mathrm{L}^{-1}\right)$ & $11-121$ \\
\hline $\mathrm{TN}\left(\mathrm{mg} \mathrm{L}^{-1}\right)$ & $254-7109$ & TDS $\left(\mathrm{mg} \mathrm{L}^{-1}\right)$ & $12700-24380$ \\
\hline $\mathrm{TP}\left(\mathrm{mg} \mathrm{L}^{-1}\right)$ & $210-740$ & Alkalinity (mg $\mathrm{CaCO}_{3}$ per L) & $14230-16890$ \\
\hline $\mathrm{COD}\left(\mathrm{mg} \mathrm{L}^{-1}\right)$ & 3600-19906 & $\mathrm{NH}_{3}\left(\mathrm{mg} \mathrm{L}^{-1}\right)$ & $254-7100$ \\
\hline $\mathrm{K}\left(\mathrm{mg} \mathrm{L} \mathrm{L}^{-1}\right)$ & $863-2250$ & Conductivity $\left(\mathrm{mS} \mathrm{cm}^{-1}\right)$ & $13.08-43.7$ \\
\hline $\mathrm{S}\left(\mathrm{mg} \mathrm{L}{ }^{-1}\right)$ & $505-1500$ & $\mathrm{PO}_{4}\left(\mathrm{mg} \mathrm{L}^{-1}\right)$ & $180-740$ \\
\hline $\mathrm{Na}\left(\mathrm{mg} \mathrm{L}^{-1}\right)$ & $508-3730$ & $\mathrm{NO}_{3}\left(\mathrm{mg} \mathrm{L}^{-1}\right)$ & $9.74-10.26$ \\
\hline $\mathrm{Cl}\left(\mathrm{mg} \mathrm{L}^{-1}\right)$ & $3000-5346$ & $\mathrm{NO}_{2}\left(\mathrm{mg} \mathrm{L}^{-1}\right)$ & $44.18-45.22$ \\
\hline $\mathrm{Ca}\left(\mathrm{mg} \mathrm{L}^{-1}\right)$ & $(17.7-32)$ & $\mathrm{SO}_{4}\left(\mathrm{mg} \mathrm{L}^{-1}\right)$ & $681-1500$ \\
\hline
\end{tabular}

1.2-1.5 L, and the annual discharge is about 400-500 L. ${ }^{29}$ The composition of urine is complicated, water makes up more than $90 \%$ of the urine, and the other $10 \%$ is composed of urea, dissolved ions, creatinine, organic and inorganic compounds and salts. ${ }^{30,31}$ Different living conditions, such as age, gender, eating habits, geographic location, income and local culture, can affect the specific components and characteristics. ${ }^{32}$ Table 1 shows the main composition and properties of human urine..$^{31,33-36}$

\subsection{Hydrolysis of human urine}

In fresh urine, urea accounts for approximately $90 \%$ of the total nitrogen (TN), other organic nitrogen accounts for $5 \%$, and ammonium accounts for the remainder. ${ }^{37}$ Once exposed to air, urine will decompose to produce ammonia $\left(\mathrm{NH}_{3}\right), \mathrm{NH}_{4}{ }^{+}$and $\mathrm{HCO}_{3}{ }^{-}$(eqn (1)), a process catalyzed by urease, and an increase of the urine pH occurs. Enzymatic urea hydrolysis can cause a number of problems, for example, deposition of the products formed. According to the composition, these scaling substances are classified as struvite (magnesium ammonium phosphate, $\left.\mathrm{MgNH}_{4} \mathrm{PO}_{4} \cdot 6 \mathrm{H}_{2} \mathrm{O}\right),{ }^{4}$ hydroxyapatite $\left(\mathrm{HAP}, \mathrm{Ca}_{10}\left(\mathrm{PO}_{4}\right)_{6}(\mathrm{OH})_{2}\right){ }^{38}$ and potassium struvite (struvite-(K), $\mathrm{KMgPO}_{4} \cdot 6 \mathrm{H}_{2} \mathrm{O}$ ). ${ }^{39}$ In particular, the reaction between $\mathrm{Mg}^{2+}, \mathrm{PO}_{4}{ }^{3-}, \mathrm{NH}_{4}{ }^{+}$and $\mathrm{H}_{2} \mathrm{O}$ produces struvite (eqn (2)), the reaction between $\mathrm{PO}_{4}{ }^{3-}, \mathrm{Ca}^{2+}$ and $\mathrm{OH}^{-}$produces HAP (eqn (3)), and the reaction between $\mathrm{K}^{+}$, $\mathrm{Mg}^{2+}, \mathrm{PO}_{4}{ }^{3-}$ and $\mathrm{H}_{2} \mathrm{O}$ produces potassium struvite (eqn (4)). Struvite deposition often occurs spontaneously at a pH of 7-8, and then HAP sediment occurs at a higher $\mathrm{pH} .^{38,40}$ This may be related to the difference between supersaturation, ${ }^{\mathbf{4 1}}$ because the saturation of struvite is $4.33 \times 10^{-14}$, whereas the saturation of HAP is $2.91 \times 10^{-58}$. These precipitates are found attached to urinal traps, drain lines and storage tanks during the excretion, collection and storage of urine, causing a significant inconvenience during urine transportation. Another disadvantage of urea hydrolysis is the unpleasant odor. There is an equilibrium between $\mathrm{NH}_{4}{ }^{+}$and $\mathrm{NH}_{3}$, and an equilibrium between $\mathrm{NH}_{3}$ solution and $\mathrm{NH}_{3}$ gas, whose main driving force is $\mathrm{pH} .{ }^{4}$ When the $\mathrm{pH}$ is between 4 and 7 , ammonia nitrogen transforms between $\mathrm{NH}_{4}{ }^{+}$and $\mathrm{NH}_{3}$ (eqn (5)). When the $\mathrm{pH}$ is higher than 7, the $\mathrm{NH}_{3}$ dissolved in the liquid will convert to $\mathrm{NH}_{3}$ gas and escape into the air (eqn (6)), which continuously causes an unpleasant smell. The urine decay process is another name for these processes. The smell of urine grows stronger as the process progresses, and more scaling is produced. After that, fresh urine is hydrolyzed.

$$
\begin{gathered}
\mathrm{NH}_{2}(\mathrm{CO}) \mathrm{NH}_{2}+2 \mathrm{H}_{2} \mathrm{O} \stackrel{\text { urease }}{\longrightarrow} \mathrm{NH}_{3}+\mathrm{NH}_{4}{ }^{+}+\mathrm{HCO}_{3}{ }^{-} \\
\mathrm{Mg}^{2+}+\mathrm{PO}_{4}{ }^{3-}+\mathrm{NH}_{4}{ }^{+}+\mathrm{H}_{2} \mathrm{O} \rightarrow \mathrm{MgNH}_{4} \mathrm{PO}_{4} \cdot 6 \mathrm{H}_{2} \mathrm{O} \\
3 \mathrm{PO}_{4}{ }^{3-}+5 \mathrm{Ca}^{2+}+\mathrm{OH}^{-} \rightarrow \mathrm{Ca}_{5}(\mathrm{OH})\left(\mathrm{PO}_{4}\right)_{3} \\
\mathrm{~K}^{+}+\mathrm{Mg}^{2+}+\mathrm{PO}_{4}{ }^{3-}+\mathrm{H}_{2} \mathrm{O} \rightarrow \mathrm{KMgPO}_{4} \cdot 6 \mathrm{H}_{2} \mathrm{O} \\
\mathrm{NH}_{3}(\mathrm{aq})+\mathrm{H}^{+} \rightleftharpoons \mathrm{NH}_{4}^{+}(4<\mathrm{pH}<7) \\
\mathrm{NH}_{3}(\mathrm{aq}) \rightleftharpoons \mathrm{NH}_{3}(\mathrm{~g})(7<\mathrm{pH}<9.5)
\end{gathered}
$$

In urine collection and storage, stabilizing the urine is the most important process. The optimum $\mathrm{pH}$ for urease is 6.88.7. ${ }^{42}$ As a result, inactivating urease by $\mathrm{pH}$ regulation is a viable strategy. To prevent urine hydrolysis, solid $\mathrm{Ca}(\mathrm{OH})_{2}$ can be placed in the urine tank to increase the $\mathrm{pH}$ to above $12.5 .^{43} \mathrm{In}$ addition, adding enzyme inhibitors and using electrochemical treatment can help to stabilize the urine. ${ }^{44}$ Another solution is to accelerate urine hydrolysis on-site. Installation of a urea hydrolysis reactor in the toilet can speed up urea hydrolysis, and allows for the controlled collection of phosphate and $\mathrm{NH}_{3} \cdot{ }^{45}$

\section{Membrane technologies for urine resource utilization}

Fig. 2 shows the evolution of membrane technologies in the utilization of human urine resources after 2016, and membrane research has increased every year since then. Forward osmosis (FO), membrane distillation (MD), electrodialysis (ED) have always been research hotspots, and FO has received the most attention. There has been less research on reverse osmosis (RO) and nanofiltration (NF). The membrane bioreactor (MBR) has only been used in combined processes in recent years. Furthermore, hybrid processes combining various membrane technologies are gradually gaining traction, with the FO-MD process gaining the most attention. The specific process will be discussed in greater depth later, and combined processes in the form of the main process and the auxiliary process will be introduced. 


\section{Single process}

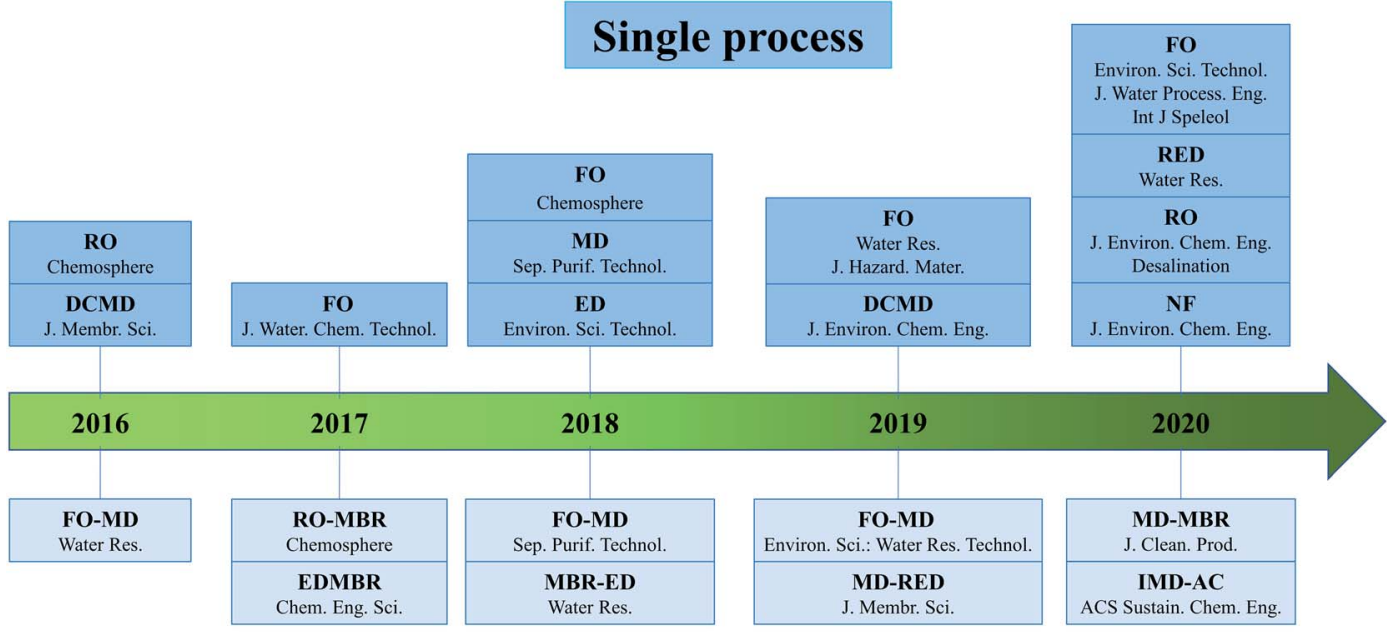

\section{Combined process}

Fig. 2 A timeline of the development of membrane processes (specific references to the literature are shown in the text of S1, ESI $\dagger$ ).

\subsection{External pressure-driven membrane technology}

External pressure-driven membrane related technology includes microfiltration (MF), ultrafiltration (UF), NF, RO and MBR. The MF and UF are low-pressure processes, which can retain bacteria and large particles, but $\mathrm{N}, \mathrm{P}$ and soluble organic matter can pass through the membrane. ${ }^{46}$ High-pressure membranes, such as NF and RO, have better interception effects but require a lot of energy. Activated sludge degrades organic matter and converts ammonia nitrogen into nitrogenous nitrogen in the MBR process, while a membrane is used for solid-liquid separation. Only a combined process of MF, UF and MBR can recycle urine. Table 2 shows recent research on external pressure-driven technologies for urine resource utilization.

Urine hydrolysis and the $\mathrm{pH}$ value will affect the nutrient recovery efficiency due to the existence of acidic functional groups in the membrane. On the one hand, hydrolysis of urine produces $\mathrm{NH}_{4}{ }^{+}$, the anion was first rejected by the membrane, and then $\mathrm{NH}_{4}{ }^{+}$was more easily retained due to the electroneutrality principles. ${ }^{47}$ On the other hand, a high $\mathrm{pH}$ not only

Table 2 The application of external pressure-driven membrane technologies ${ }^{a}$

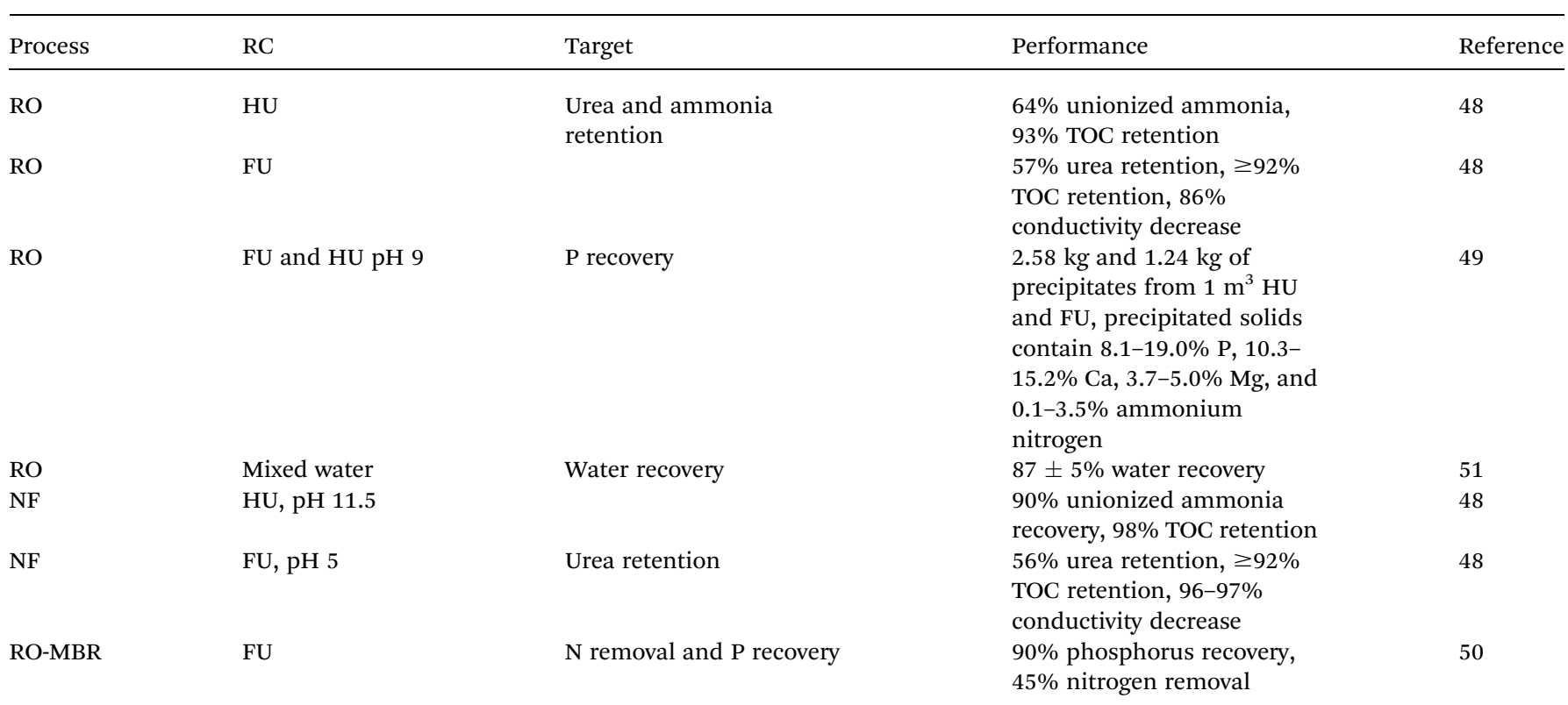

${ }^{a}$ Note: FU - fresh urine, HU - hydrolyzed urine, RC - reaction conditions, TOC - total organic carbon. 
converted $\mathrm{NH}_{4}{ }^{+}$into $\mathrm{NH}_{3}$ but also lead to electrostatic repulsion of these acidic functional groups, resulting in pore expansion. ${ }^{48,49}$ Ray et al. ${ }^{47}$ investigated urea and $\mathrm{NH}_{3}$ rejection in hydrolyzed and fresh urine by RO and NF. For hydrolyzed urine, $64 \%$ of unionized $\mathrm{NH}_{3}$ was recovered by $\mathrm{RO}$, and $90 \%$ of unionized $\mathrm{NH}_{3}$ was recovered by NF. At a $\mathrm{pH}$ of 11.5 , the $\mathrm{NF}$ membrane would achieve 90\% unionized $\mathrm{NH}_{3}$ recovery, $86 \%$ conductivity reduction and $98 \%$ TOC rejection. For fresh urine, NF rejected $42-56 \%$ of urea and the base addition would decrease the rejection. The RO could reject $57 \%$ of urea and was not affected by the $\mathrm{pH}$ because the RO membranes have tighter pores.

In addition to the RO membrane, RO brine can be used to recover $P$ from source-separated urine. One of the main sources of RO brine is cooling water from thermal power plants. ${ }^{50}$ When the RO brine-to-urine ratio was $1: 1$ and the $\mathrm{pH}$ was 9.0, more than $90 \%$ of the phosphorus could be removed from both fresh urine and hydrolysis urine. From $1 \mathrm{~m}^{3}$ of fresh urine, approximately $1.24 \mathrm{~kg}$ of precipitates could be obtained, whereas 2.58 $\mathrm{kg}$ of precipitates could be obtained from the same volume of hydrolyzed urine. The precipitates contained $0.1-3.5 \%$ of ammonium nitrogen, $3.7-5.0 \%$ of $\mathrm{Mg}, 10.3-15.2 \%$ of $\mathrm{Ca}$, and 8.1-19.0\% of P. Furthermore, using RO brine to flush urinediverting toilets can achieve on-site phosphorus recovery from human urine..$^{51}$ Nitrogen can be removed in an MBR process after phosphorus precipitation via a short-cut nitrificationdenitrification. When the $\mathrm{pH}$ was greater than $9,90 \%$ of the phosphorus in the precipitation process was recovered, with recovered precipitates containing $10-15 \%$ of phosphorus. Without using an external carbon source, the MBR process removed $45 \%$ of the TN. The COD and nitrogen removal was $90 \%$ when $3 \mathrm{~g} \mathrm{~L}^{-1}$ of methanol was added.

In the field of manned space flight, external pressure-driven membrane technologies play an important role. In long-term human space missions, ${ }^{52}$ electrodialysis is integrated with crystallization, COD-removal, ammonification, and nitrification in long-term human space missions to treat human urine $(1.2 \mathrm{~L}$ $\mathrm{d}^{-1}$ ) before it was mixed with shower water. Electrodialysis was used specifically to recover $\mathrm{NO}^{3-}$, and $\mathrm{RO}$ was the final step to recover clean water from the mixture of shower water and treated urine.

\subsection{Vapor pressure-driven membrane technology}

The MD is a non-isothermal separation membrane technology driven by a vapor-pressure gradient, ${ }^{53,54}$ which is widely used in various fields and has four configurations: (1) air gap membrane distillation (AGMD), (2) direct contact membrane distillation (DCMD), (3) sweep gas membrane distillation (SGMD), (4) vacuum membrane distillation (VMD). ${ }^{55-57}$ The MD can completely reject non-volatile matter, and the salt concentration in the feed solution has little influence on its efficiency. ${ }^{58,59}$ The research on MD for urine resource utilization in recent years are shown in Table 3.

In terms of volume reduction and nutrient reconcentration, use of urine collected from toilets for DCMD performs admirably. ${ }^{18}$ More than $97 \%$ of $\mathrm{P}$ and $\mathrm{K}$ rejection was achieved when hydrolyzed urine was concentrated 17.8 times. Nevertheless, the $\mathrm{NH}_{3}$ concentration was increased to $11.0 \mathrm{~g}_{\mathrm{N}} \mathrm{L}^{-1}$, so the water generation quality was affected. $\mathrm{An}^{\mathrm{NH}_{3}}$ concentration in urine is frequently high in the process of recovering water from urine, and nutrients' concentration, and this resulted in free $\mathrm{NH}_{3}$ transfer through the MD membrane to the permeate.

Two important factors in $\mathrm{MD}$ are temperature and $\mathrm{pH}$. Except for pretreatment, $\mathrm{pH}$ control, temperature regulation and utilization of new membrane materials are also solutions. The water flux was more affected by temperature than the $\mathrm{NH}_{3}$ flux, and $\mathrm{NH}_{3}$ transfer can be effectively inhibited by a low $\mathrm{pH}$. Taking DCMD as an example, increasing the feed solution temperature from $40{ }^{\circ} \mathrm{C}$ to $70{ }^{\circ} \mathrm{C}$, the specific ammonia transfer (SAT) value would decrease from $8 \times 10^{-3}$ to $1.62 \times 10^{-3} \mathrm{~g}-\mathrm{N}$ per $\mathrm{g}-\mathrm{H}_{2} \mathrm{O}$. By reducing the $\mathrm{pH}$ from 9 to 5 , the SAT value decreased from $2.05 \times 10^{-3}$ to $6.91 \times 10^{-5} \mathrm{~g}-\mathrm{N}$ per $\mathrm{g}-\mathrm{H}_{2} \mathrm{O} .{ }^{60}$ In addition, water permeate flux and $\mathrm{NH}_{3}$ transfer were also determined by the membrane material. ${ }^{\mathbf{6 1 , 6 2}}$ In particular, a thin structure and high porosity help to improve the water flux. Khumalo et al. ${ }^{63}$ applied microporous hydrophobic composite membranes in membrane distillation. The membrane was made of poly(vinylidene fluoride)/poly(tetrafluoroethylene) (PVDF/PTFE), which were modified with methyl functionalized silica nanoparticles (MfSNPs). Under the conditions of a pH of 10.5 and a water vapor gradient of $30{ }^{\circ} \mathrm{C}, 80 \%$ of water was recovered

Table 3 The application of vapor pressure-driven membrane technologies ${ }^{a}$

\begin{tabular}{|c|c|c|c|c|}
\hline Process & $\mathrm{RC}$ & Target & Performance & Reference \\
\hline DCMD & FU & $\begin{array}{l}\text { Volume reduction and nutrient } \\
\text { concentration }\end{array}$ & $\begin{array}{l}\text { Urine concentrated } 17.8 \text { times, } 97 \% \mathrm{P} \text { and } \mathrm{K} \\
\text { rejection }\end{array}$ & 18 \\
\hline DCMD & & Specific ammonia transfer inhibition & SAT was reduced to $6.91 \times 10^{-5} \mathrm{~g}-\mathrm{N}$ per $\mathrm{g}-\mathrm{H}_{2} \mathrm{O}$ & 59 \\
\hline MD & $\begin{array}{l}\mathrm{HU}, \mathrm{pH} 10 \text {, water vapor } \\
\text { gradient } 30^{\circ} \mathrm{C}\end{array}$ & Water recovery & $\begin{array}{l}80 \% \text { water recovery, } 98 \% \text { of } \mathrm{TOC}, 98 \% \text { of } \mathrm{Na}^{+} \text {, and } \\
89 \% \text { of } \mathrm{K}^{+} \text {rejected }\end{array}$ & 62 \\
\hline $\begin{array}{l}\text { IMD- } \\
\text { AC }\end{array}$ & $\mathrm{HU}$ & Ammonia recovery & $60 \%$ ammonia recovery, 95\% energy saving & 63 \\
\hline FO-MD & FU & Water recovery & $98 \%$ TOC, TN, and $\mathrm{NH}_{4}^{+}$removal & 34 \\
\hline FO-MD & FU and $\mathrm{HU}$ & Water recovery & Water flux of 31.5 (FU) to 28.7 (HU) $\mathrm{L} \mathrm{m}^{-2} \mathrm{~h}^{-1}$ & 64 \\
\hline $\begin{array}{l}\text { MD- } \\
\text { MBR }\end{array}$ & $\mathrm{HU}$ & $\begin{array}{l}\text { Non-odorous high-concentration liquid } \\
\text { fertilizer production }\end{array}$ & Total dissolved solid concentration of $280 \mathrm{~g} \mathrm{~L}^{-1}$ & 65 \\
\hline
\end{tabular}




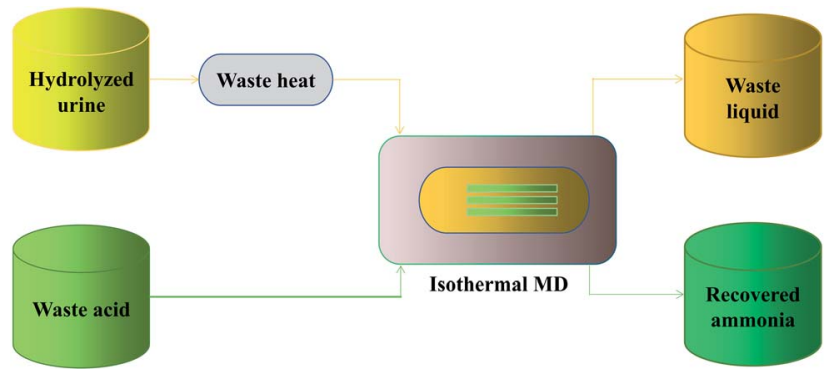

Fig. 3 The IMD-AC process.

from hydrolyzed human urine, and $95 \%$ of the $\mathrm{NH}_{3}, 98 \%$ of the TOC, $98 \%$ of the $\mathrm{Na}^{+}, 89 \%$ of the $\mathrm{K}^{+}$were rejected.

A temperature difference cannot be maintained without heating, which has a great energy demand. Another way of thinking, inhibiting the transfer of water and collecting $\mathrm{NH}_{3}$ provides an energy saving solution, as shown in Fig. 3. A novel isothermal membrane distillation with an acidic collector (IMDAC) was devised to improve selectivity for $\mathrm{NH}_{3}$ transport. ${ }^{64}$ Water vapor permeation was suppressed 68 times by keeping the feed and collector temperature equal, and $\mathrm{NH}_{3}(\mathrm{~g})$ was collected by acidic solutions to enhance the $\mathrm{NH}_{3}$ vapor. Compared with conventional MD, the IMD-AC showed an increase of $46.5 \% \mathrm{NH}_{3}$ vapor, reaching $60 \% \mathrm{NH}_{3}$ recovery. Furthermore, when compared to the traditional nitrogen fixation process, approximately $95 \%$ of the energy consumed was saved, with the final energy requirement being $2.2 \mathrm{~kW} \mathrm{~h} \mathrm{~kg}_{\mathrm{N}}{ }^{-1}$. In other words, compared to traditional MD, IMD can selectively capture volatile matter other than water and the process requires less energy.
In addition, a combined process can also achieve nitrogen retention. For example, the FO process, which has received extensive attention, can achieve effective interception of $\mathrm{NH}_{3}$. In a forward osmosis-MD (FO-MD) for real human urine treatment, more than $98 \%$ of the TOC, TN, and $\mathrm{NH}_{4}{ }^{+}$were rejected by the FO process. ${ }^{34}$ Volpin et al. ${ }^{65}$ combined FO and MD for extracting distilled water from fresh urine and stored urine. To prevent membrane wetting and improve the overall nitrogen rejection, FO was chosen as a pretreatment for MD. The combination of the FO and MD processes provided a new treatment idea for water regeneration in the space station and resource recovery in urban applications. The MBR process can convert $\mathrm{NH}_{3}$ into nitrate, which cannot pass through the MD membrane in the form of steam, but at the same time also degrades a large amount of TOC. An MBR-DCMD process has been investigated, which produces an odorless and highconcentration liquid fertilizer. ${ }^{66}$ At first, the MBR removed $95 \%$ of the TOC and converted $50 \%$ of the $\mathrm{NH}_{4}{ }^{+}-\mathrm{N}$ to $\mathrm{NO}_{3}{ }^{-}-\mathrm{N}$. Then the DCMD recovered $80 \%$ of the water and the final total dissolved solids concentration reached $280 \mathrm{~g} \mathrm{~L}^{-1}$. These results showed that DCMD could concentrate the urine 20-fold.

\subsection{Chemical potential-driven membrane technology}

The FO is a low-pressure or non-pressure membrane technology in which water is transferred from a high-concentration solution to a low-concentration solution until a thermodynamic equilibrium is achieved, with the chemical potential as the driving force. ${ }^{67,68}$ The advantages of FO include: (1) it is a lowpressure operation, which derives other advantages such as a lower propensity for fouling, lower energy demand, lower

Table 4 The application of chemical potential-driven membrane technologies ${ }^{a}$

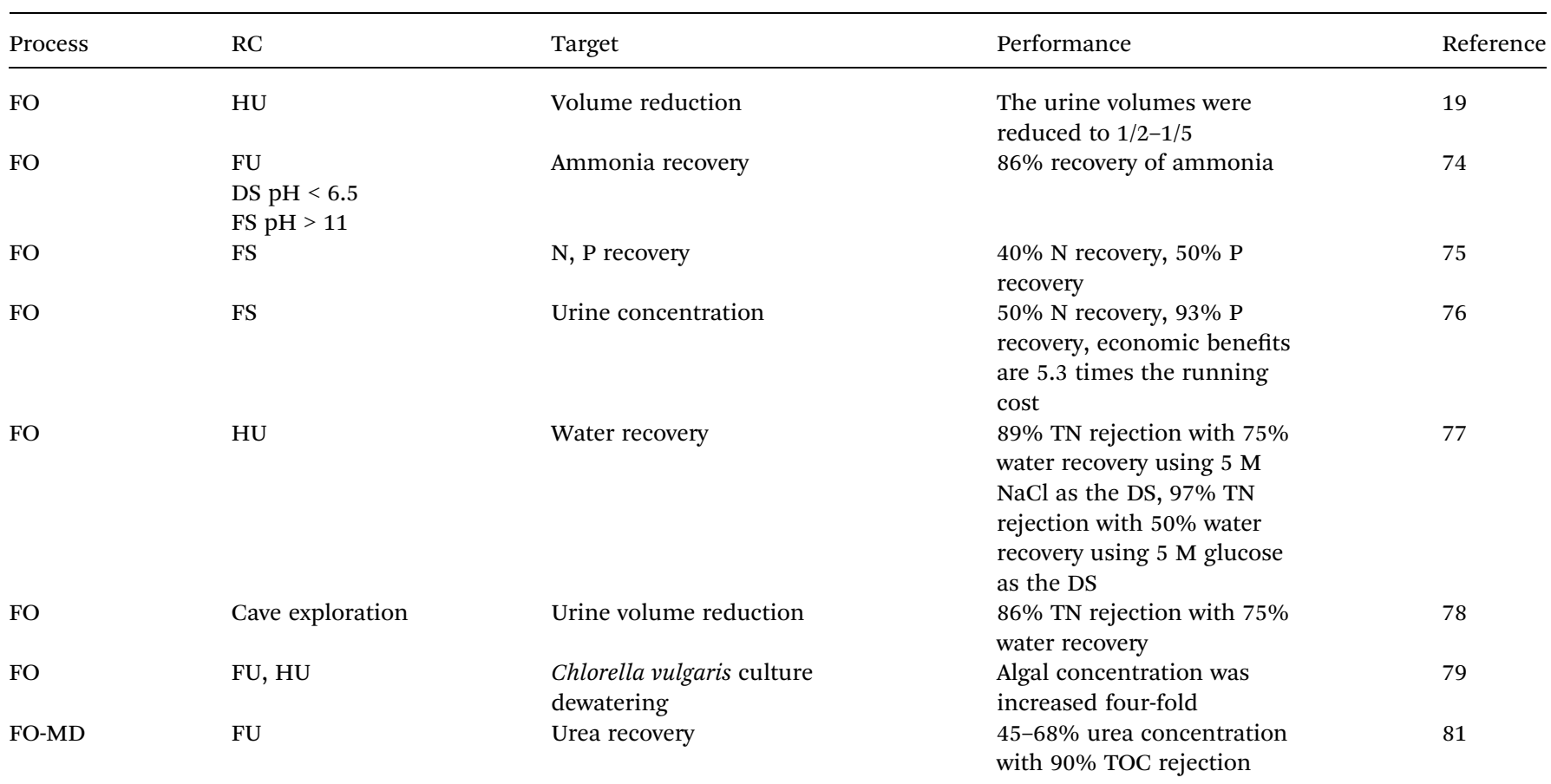

${ }^{a}$ Note: FU - fresh urine, HU - hydrolyzed urine, RC - reaction conditions. 


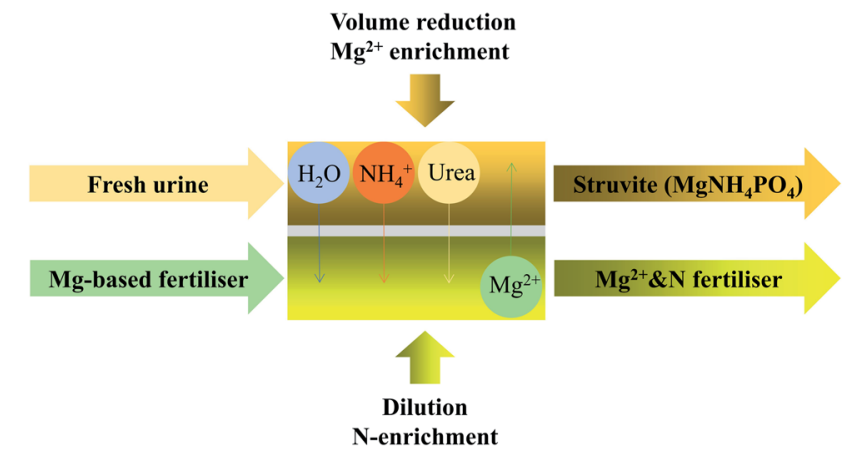

Fig. 4 The FDFO process.

membrane strength requirement, and fouling reversibility ${ }^{69}(2)$ a high rejection of pollutants, ${ }^{70,71}$ and (3) flexible use. Depending on the application, the draw solution (DS) composition can be manipulated to obtain different recovery targets. ${ }^{72}$ The FO process has been widely used in food processing, nuclear wastewater treatment, desalination, and drinking water and landfill leachate treatment because of these advantages..$^{71,73,74} \mathrm{In}$ resource utilization of urine, FO has also been widely studied, as shown in Table 4.

The volumes of both real human urine and synthetic human urine were reduced by $1 / 2-1 / 5$ using a cellulose triacetate membrane in FO, but $\mathrm{NH}_{3}$ and inorganic carbon passed through the membrane easily, about $35-40 \%$ and $30 \%$, respectively. As a result, measures to improve nutrient reduction should be taken. ${ }^{19}$

The original potential difference between the two sides of the membrane can be changed by manipulating the DS composition to prevent water or $\mathrm{NH}_{3}$ transmission. Adding electrolyte solutions or changing the $\mathrm{pH}$ of DS are two examples of specific regulatory methods. By adjusting the feed solution so that it has a high $\mathrm{pH}$ and the $\mathrm{DS}$ so it has a low $\mathrm{pH},{ }^{75} \mathrm{NH}_{3}$ is transformed into $\mathrm{NH}_{4}{ }^{+}$upon crossing over the FO membrane. By keeping the $\mathrm{DS}$ at $\mathrm{pH}<6.5$ and the feed solution $\mathrm{pH}>11$, the $\mathrm{NH}_{3}$ recovery rate achieved was up to $86 \%$. Magnesium salts are an ideal electrolyte additive because $\mathrm{Mg}^{2+}$ is one of the plant nutrients, and it can precipitate with $\mathrm{P}$ to produce struvite. In terms of agricultural utilization, Volpin et al. ${ }^{76}$ employed fertilizer driven FO to recover $\mathrm{N}$ and $\mathrm{P}$ from human urine, as shown in Fig. 4. The $\mathrm{MgSO}_{4}$ and $\mathrm{Mg}\left(\mathrm{NO}_{3}\right)_{2}$ were chosen as the DSs for dewatering synthetic non-hydrolyzed urine, and $\mathrm{Mg}^{2+}$ reverse salt flux was selected to precipitate the $\mathrm{P}$ as struvite. At the same time, urea was concentrated in the DS because the FO membrane had a poor interception effect on it. The fertilizerdrawn forward osmosis (FDFO) process recovered $40 \%$ of $\mathrm{N}$ and $50 \%$ of $\mathrm{P}$ while reducing the volume of urine by more than $60 \%$. Following a preliminary investigation, use of a commercial fertilizer as a FO draw solution was developed. ${ }^{77}$ With $50 \%$ concentrated urine, $93 \%$ of the $\mathrm{P}$ was recovered as struvite, and $50 \%$ of the $\mathrm{N}$ was recovered in the diluted DS. When the downstream nutrient load is reduced, the economic benefits would be 5.3 times the operating cost.

Urine hydrolysis has a significant impact on the FO process, which is influenced by $\mathrm{pH}$ and the enzyme urease. Engelhardt et al. ${ }^{78}$ used hollow fiber, aquaporin-based membranes for $\mathrm{NH}_{3}$ rejection and water recovery to improve the nitrogenous compound rejection, and $\mathrm{pH}$ control was also used. The results showed that the best $\mathrm{pH}$ for urea hydrolysis was 7.4, and by using urease-processing and $\mathrm{pH}$ adjustment, the $\mathrm{TN}$ rejection could reach $89 \%$ (with $75 \%$ water recovery) to $98 \%$ (with $25 \%$ water recovery), using $5 \mathrm{M} \mathrm{NaCl}$ as the DS. When using $5 \mathrm{M}$ glucose as the DS, the $\mathrm{NH}_{3}$ recovery ranged from $97 \%$ (with $50 \%$ water recovery) to $99 \%$ (with $25 \%$ water recovery). Following that, the performance of an Aquaporin Inside hollow fiber FO module (Sterlitech) used for urine volume reduction without DS for long-duration cave expeditions was tested, and a portable FO prototype was introduced, which was able to reduce the urine volume by approximately $75 \%$ and reject approximately $86 \%$ of the TN. ${ }^{79}$

In addition to the nutrient and water recovery, the urine-FO combination can be used in other fields, such as microalgae culture. ${ }^{80}$ The concentration of algae increased by four times with a water flux of $14.2 \mathrm{~L} \mathrm{~m}^{-2} \mathrm{~h}^{-1}$ using hydrolyzed urine as the DS. The diluted urine could be used as a nutrition source and pharmaceuticals could be removed via biodegradation and photolysis. ${ }^{81}$

A combined process to improve FO performance did not appear to be required because the single FO process has a satisfactory effect on urine treatment. The FO process, on the other hand, is occasionally used as a pretreatment for the MD process. To recover urea from fresh human urine, for example, an FO-MD method has been developed. ${ }^{82}$ Urea separation was accomplished with FO, and urea concentration reduction was accomplished with MD. After five pretreatment methods used for urine stabilization, the FO process recovered $11-21 \%$ of the urea in the DS, then the draw solutions were concentrated 1.9-

Table 5 The application of electric field-driven membrane technologies ${ }^{a}$

\begin{tabular}{lllll}
\hline Process & RC & Target & Performance & Reference \\
\hline ED & & Nitrogen recovery & $95.6 \%$ nitrogen recovery & \\
EDMBR & HU & Phosphate and sulfate recovery & $65 \%$ phosphate recovery, $54.9 \%$ sulfate recovery \\
MBR-ED & FU & Urine treatment & $80 \%$ ion collection & 87 \\
RED & FU and HU & Energy recovery & A maximum $E_{\text {Net }}$ of $0.053-0.039 \mathrm{~kW} \mathrm{~h} \mathrm{~m}^{-3}$ of real urine & 85 \\
MD-RED & & Water and energy recovery & $47 \%$ Gibbs free energy recovery & 90
\end{tabular}

${ }^{a}$ Note: FU - fresh urine, HU - hydrolyzed urine, RC - reaction conditions. 
3.3 times via the MD process. The product solution contained $45-68 \%$ of the urea concentration of fresh urine and $90 \%$ of the TOC was rejected.

\subsection{Electric field-driven membrane technology}

The ED is an electrochemical membrane separation technology driven by an applied electric field, ${ }^{83}$ which consists of a anion exchange membrane (AEM), a cation exchange membrane (CEM) and a direct current electric field. Due to its ability to generate high-quality nutrient products successfully, ${ }^{84}$ ED has been extensively used, especially in the demineralization of industrial processes and desalination of brackish water, with a treatment capacity of more than $20000 \mathrm{~m}^{3} \mathrm{~d}^{-1} .^{85}$ In urine treatment (Table 5), the purposes of ED include: (1) water or nutrient recovery, (2) urine desalination, and (3) micropollutant removal. ${ }^{86}$

Tarpeh et $a l .{ }^{87}$ used an electrochemical stripping setup that included ED and membrane stripping to recover nitrogen from source-separated urine. In batch experiments, $93 \%$ of the nitrogen was recovered selectively. In continuous-flow experiments, when the influent concentration was $7490 \mathrm{mg}_{\mathrm{N}} \mathrm{L}^{-1}$, the nitrogen concentration was $2960 \mathrm{mg}_{\mathrm{N}} \mathrm{L}^{-1}$ in the anode chamber, $1950 \mathrm{mg}_{\mathrm{N}} \mathrm{L}^{-1}$ in the cathode chamber, $2250 \mathrm{mg}_{\mathrm{N}} \mathrm{L}^{-1}$ in the trapped chamber after 3-5 hydraulic residence times (HRT), and the energy demand was $30.6 \mathrm{MJ} \mathrm{kg}_{\mathrm{N}}{ }^{-1}$. In addition, in the ammonium sulfate fertilizer product, there were no trace organics or elements detected.

However, because it is difficult to consider both pollutant removal and nutrient recovery in a single ED process, combined processes or a pretreatment for the ED are required. The combination of $\mathrm{NH}_{3}$ stripping, ED and MBR works well for source-separated urine treatment. ${ }^{88}$ Ammonia stripping was performed as a pretreatment to decrease the $\mathrm{NH}_{3}$ concentration from $1292.2 \pm 47.5 \mathrm{mg} \mathrm{L}^{-1}$ to $235.1 \pm 5.7 \mathrm{mg} \mathrm{L}^{-1}$, which was about an $81.8 \%$ removal rate. Then phosphate and sulfate were recovered whereas the $\mathrm{NH}_{3}$ and COD were removed in situ in the EDMBR, with a power density of $23.5 \mathrm{~W} \mathrm{~m}^{-3}$. Finally, $94.5 \%$ of the $\mathrm{SO}_{4}{ }^{2-}, 76.7 \%$ of the $\mathrm{PO}_{4}{ }^{3-}$, and $97.4 \%$ of the $\mathrm{NH}_{4}{ }^{+}$was removed, whereas the phosphate and sulfate were recovered as

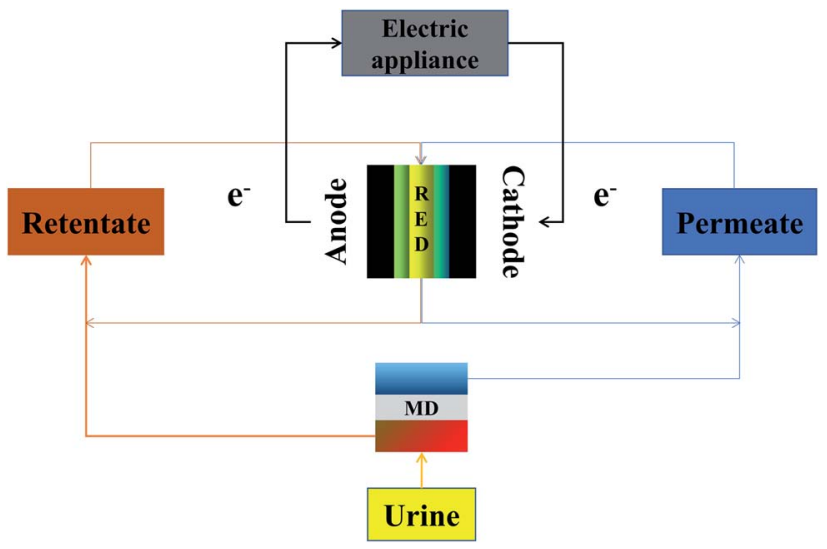

Fig. 5 The MD-RED process a concentrated solution, with recovery rates of $65 \%$ and $54.9 \%$, respectively. To avoid precipitation and remove organics, researchers ${ }^{86}$ combined precipitation, MBR and ED in a pilot installation for the treatment of human urine. The process was continuously run for seven months with a treatment capacity of 1.2 $\mathrm{L} \mathrm{d}^{-1}$ (one person equivalent). More than 95\% of the urea was converted into nitrate under salinities of $10-20 \mathrm{~ms} \mathrm{~cm}^{-1}$, and $70 \%$ of the ions were collected in $15 \%$ of the initial volume using a $20 \%$ urine solution $(1.2 \mathrm{~L}$ of urine and 4.6 L of demineralized water), and $80 \%$ of the ions were collected in $20 \%$ of the initial volume using a $40 \%$ urine solution $(1.3 \mathrm{~L}$ of urine and $2.2 \mathrm{~L}$ of demineralized water).

Using electric energy, traditional ED can be used to recover nutrients. The introduction of reverse electrodialysis (RED) in recent years has made it possible to convert potential energy into electrical energy. ${ }^{89}$ According to Volpin et al., ${ }^{90}$ there is a large salinity gradient between urine and flushing water that could be used as a source of potential energy. When homogenous redox couples were used as an electrolyte solution, the RED device could achieve a maximum $E_{\text {Net }}$ of $0.053-0.039 \mathrm{~kW} \mathrm{~h}$ $\mathrm{m}^{-3}$ of real urine, with $13 \%, 6 \%, 4.4 \%$ removal of TOC, $\mathrm{NH}_{3}$ and urea, respectively. Nutrient and energy recovery cannot be realized at the same time by RED, and combined processes are still needed. The MD was an ideal pre-process for RED to generate electrical power and clean water from waste heat and human urine, as shown in Fig. 5. ${ }^{91}$ Using waste heat, MD was used to produce high-quality water from urine, and the concentrated urine with a high nutrient concentration was used as the retentate in RED. The RED, on the other hand, was used to generate electrical power. In that process, $47 \%$ of the available Gibbs free energy was recovered, and low power fluidic devices with $100 \%$ water recovery in MD can be used.

\section{Conclusions and future prospects}

Membrane technology has good prospects for the utilization of resources in urine collected from toilets. The energy consumption of low external pressure membrane technologies is low, but the interception effect is poor. A high external pressure membrane has a good interception effect, but its energy consumption is high, so it is not suitable for urine resource treatment alone. Vapor pressure-driven membrane technology has a high rejection rate for non-volatile substances, but volatile substances easily pass through the membrane and pollute the product. When using urine for water recovery, precautions should be taken to prevent $\mathrm{NH}_{3}$ volatilization. Ammonia can also be recovered under isothermal conditions. The advantages of chemical potential gradient driven membrane technology include low energy consumption and ease of use. Chemical potential gradient driven membrane technology can be used in a variety of situations because the composition of the draw solution can be adjusted flexibly to accommodate different components of urine or different recovery goals. It can also be combined with other technologies to improve nutrient recovery and pollutant removal. There is little research on electric field-driven membrane technology, 
but reverse electrodialysis technology is the only one that can recover energy, making it very promising technology.

The membrane process used should be chosen based on the specific situation and for the particular construction of the source-separation toilet itself. For example, in water-stressed areas, the $\mathrm{MD}$ process is an excellent way to recover clean water. The IMD, FO, and RED processes can all have more effective roles in energy conservation. A combination process, on the other hand, may be the best option for achieving more comprehensive nutrient recovery. At the same time, MBR is still the most effective way to deal with the remaining waste after resource utilization. From current process development, the FO-MBR combined process shows a good recovery effect, low energy consumption, and the good removal of pollutants. Therefore, the FO-MBR combined process is recommended as a preliminary system for resource utilization and as a harmless treatment for urine.

At present, the application of membrane technologies in the utilization of resources from urine collected from toilets is mostly done at the laboratory scale. For existing technologies, larger-scale trials need to be conducted in the future to achieve the purpose of their final application with the help of engineering. At the same time, operational parameters should be optimized constantly to enhance pollution interception efficiency and nutrient recovery productivity, as well as to reduce membrane fouling and energy consumption. Additionally, the disposal of the final waste after urine recycling needs to be taken into consideration, which was not reported in previous research. For future research, the combination of FO and commercial fertilizer shows great potential. Facing the problem of energy shortages, the application of RED for energy recovery would be a good choice. In addition, integrated technologies bring many opportunities. For example, the application of solar energy technology on $\mathrm{MD}$, and the combination of a high concentration of microalgae and FO. There are more unknown processes waiting to be exploited. Finally, a set of evaluation systems based on membrane pollution and economic benefits should be established as these membrane technologies and processes mature.

\section{Author contributions}

The manuscript was written through with contributions from all the authors. All the authors have approved the final version of the manuscript.

\section{Conflicts of interest}

There are no conflicts to declare.

\section{Acknowledgements}

This research was financially supported by the National Natural Science Foundation of China (No. 51878465). The authors gratefully acknowledge support from the National Key R\&D Programme of China (2018YFD1100500).

\section{References}

1 G. L. Zang, G. P. Sheng, W. W. Li, Z. H. Tong, R. J. Zeng and C. Shi, Phys. Chem. Chem. Phys., 2012, 14, 1978-1984.

2 M. Maurer, P. Schwegler and T. A. Larsen, Water Sci. Technol., 2003, 48, 37-46.

3 T. Khin and A. P. Annachhatre, Biotechnol. Adv., 2004, 22, 519-532.

4 A. Patel, A. A. Mungray and A. K. Mungray, Chemosphere, 2020, 259, 127372.

5 J. G. Chen, R. M. Crooks, L. C. Seefeldt, K. L. Bren, R. M. Bullock, M. Y. Darensbourg, P. L. Holland, B. Hoffman, M. J. Janik and A. K. Jones, Sci. Total Environ., 2018, 360, 6391.

6 P. Ledezma, P. Kuntke, C. Buisman, J. Keller and S. Freguia, Trends Biotechnol., 2015, 33, 214-220.

7 J. W. Erisman, M. A. Sutton, J. Galloway, Z. Klimont and W. Winiwarter, Nat. Geosci., 2008, 1, 636-639.

8 B. VinnerS and H. J Nsson, Bioresour. Technol., 2002, 84, 275282.

9 A. Yaa, B. Sla and B. Tat, Sustain. Prod. Consum., 2020, 24, 219-231.

10 M. Ronteltap, M. Maurer and W. Gujer, Water Res., 2007, 41, 1859-1868.

11 G. Houillon and O. Jolliet, J. Cleaner Prod., 2005, 13, 287-299.

12 T. A. Larsen and W. Gujer, Water Sci. Technol., 1996, 34, 8794.

13 C. Bonvin and B. Etter, Ambio, 2015, 44, 217-227.

14 L. Rossi, J. Lienert and T. A. Larsen, J. Environ. Manage., 2009, 90, 1909-1917.

15 M. U. Kai, C. A. Buckley, M. Wächter, C. S. Mcardell, T. Kohn, L. Strande, H. Zöllig, A. Fumasoli, A. Oberson and B. Etter, Water SA, 2016, 41, 212-221.

16 K. M. Lamichhane and R. W. Ba Bcock, Sci. Total Environ., 2013, 443, 749-756.

17 P. Simha and M. Ganesapillai, Sustainable Environ. Res., 2016, 27, 107-116.

18 K. Xu, D. Qu, M. Zheng, X. Guo and C. Wang, J. Environ. Eng., 2019, 145, 04018144.

19 W.-Y. N. Benedicte Carolle, I. Ryusei and G. Mokhtar, J. Water Environ. Technol., 2017, 15, 163-173.

20 M. Maurer, W. Pronk and T. A. Larsen, Water Res., 2006, 40, 3151-3166.

21 S. K. L. Ishii and T. H. Boyer, Water Res., 2015, 79, 88-103.

22 M. Dimitris, P. Maria, T. Nikolaos, P. Dimitrios and K. Efstratios, Chem. Eng. J., 2018, 347, 618-630.

23 P. Simha, J. Senecal, A. Nordin, C. Lalander and B. Vinneras, Water Res., 2018, 142, 325-336.

24 B. B. Lind, Z. Ban and S. Bydén, Ecol. Eng., 2001, 16, 561-566. 25 S. Antonini, P. T. Nguyen, U. Arnold, T. Eichert and J. Clemens, Sci. Total Environ., 2012, 414, 592-599.

26 S. G. Barbosa, L. Peixoto, O. Soares, M. Pereira, A. T. Heijne, P. Kuntke, M. M. Alves and M. A. Pereira, Electrochim. Acta, 2018, 26, 122-132.

27 A. Tremouli, J. Greenman and I. Ieropoulos, Bioelectrochemistry, 2018, 123, 19-25. 
28 S. Bouatra, F. Aziat, R. Mandal, C. G. An, M. R. Wilson, C. Knox, T. C. Bjorndahl, R. Krishnamurthy, F. Saleem and P. Liu, PLoS One, 2013, 8, e73076.

29 E. J. Saude and B. D. Sykes, Metabolomics, 2007, 3, 19-27.

30 T. Karak and P. Bhattacharyya, Resour., Conserv. Recycl., 2011, 55, 400-408.

31 K. M. Udert, T. A. Larsen and W. Gujer, Water Sci. Technol., 2006, 54, 413-420.

32 R. G. Feachem, D. J. Bradley and H. Garelick, Water Res., 1985, 19, 131.

33 S. Hassan, H. I. Abdel-Shafy and M. Mansour, Arabian J. Chem., 2016, 12, 4074-4083.

34 Q. Liu, C. Liu, L. Zhao, W. Ma, H. Liu and J. Ma, Water Res., 2016, 91, 45-54.

35 W. Pronk, M. Biebow and M. Boller, Environ. Sci. Technol., 2006, 40, 2414-2420.

36 W. Pronk, H. Palmquist, M. Biebow and M. Boller, Water Res., 2006, 40, 1405-1412.

37 C. Höglund, B. Vinnerås, T. A. Stenström and H. Jönsson, J. Environ. Sci. Health, 2000, 35, 1463-1475.

38 M. U. Kai, T. A. Larsen, M. Biebow and W. Gujer, Water Res., 2003, 37, 2571-2582.

39 J. A. Wilsenach, C. Schuurbiers and M. Loosdrecht, Water Res., 2007, 41, 458-466.

40 E. Tilley, J. Atwater and D. Mavinic, Environ. Technol., 2008, 29, 807-816.

41 L. C. Bell, H. Mika and B. J. Kruger, Arch. Oral Biol., 1978, 23, 329-336.

42 H. L. T. Mobley and R. P. Hausinger, Microbiol. Rev., 1989, 53, 85-108.

43 C. P. Flanagan and D. G. Randal, J. Environ. Chem. Eng., 2018, 6, 6344-6350.

44 M. Ikematsu, K. Kaneda, M. Iseki and M. Yasuda, Sci. Total Environ., 2007, 382, 159-164.

45 E. R. Marlies, J. V. De, L. Clinckemaillie, R. Ganigué and K. Rabaey, Water Res., 2018, 148, 97-105.

46 F. Li, J. Behrendt, K. Wichmann and R. Otterpohl, Water Sci. Technol., 2008, 57, 1901-1907.

47 H. Ray, F. Perreault and T. H. Boyer, J. Environ. Chem. Eng., 2020, 8, 103993.

48 C. Bellona, J. E. Drewes, P. Xu and G. Amy, Water Res., 2004, 38, 2795-2809.

49 P. Berg, G. Hagmeyer and R. Gimbel, Desalination, 1997, 113, 205-208.

50 X. Tian, G. Wang, D. Guan, J. Li, A. Wang, J. Li, Z. Yu, Y. Chen and Z. Zhang, Chemosphere, 2016, 165, 202-210.

51 S. Yao, L. Chen, D. Guan, Z. Zhang, X. Tian, A. Wang, G. Wang, Q. Yao and D. Peng, Chemosphere, 2017, 175, 210-218.

52 B. Refla, A. Jdp, C. Mv, D. Afa, A. Wc, H. Aaa, A. Merc, E. Cd, E. $\mathrm{Hb}$ and $\mathrm{F}$. Bl, Desalination, 2020, 495(114634).

53 T. S. Chung and S. Y. Yan, Chem. Eng. J., 2011, 171, 684-691.

54 A. Alkhudhiri, N. Darwish and N. Hilal, Desalination, 2012, 287, 2-18.

55 M. Shirazi, A. Kargari and M. Tabatabaei, Chem. Eng. Process., 2014, 76, 16-25.
56 M. S. El-Bourawi, Z. Ding, R. Ma and M. Khayet, J. Membr. Sci., 2006, 285, 4-29.

57 M. Khayet, Adv. Colloid Interface Sci., 2011, 164, 56-88.

58 D. L. Shaffer, L. Chavez, M. Ben-Sasson, R. V. Castrillon, N. Y. Yip and M. Elimelech, Environ. Sci. Technol., 2013, 47, 9569-9583.

59 D. Adams and A. E. Childress, J. Membr. Sci., 2005, 257, 111119.

60 L. L. Tun, D. Jeong, S. Jeong, K. Cho, S. Lee and H. Bae, J. Membr. Sci., 2016, 512, 13-20.

61 T. Duong, Z. Xie, D. Ng and M. Hoang, Water Environ. J., 2013, 27, 425-434.

62 Y. M. Manawi, M. Khraisheh, A. K. Fard, F. Benyahia and S. Adham, Desalination, 2014, 336, 110-120.

63 N. Khumalo, L. Nthunya, S. Derese, M. Motsa and D. S. Dlamini, Sep. Purif. Technol., 2018, 211, 610-617.

64 S. N. McCartney, N. A. Williams, C. Boo, X. Chen and N. Y. Yip, ACS Sustainable Chem. Eng., 2020, 8, 7324-7334.

65 F. Volpin, L. Chekli, S. Phuntsho, N. Ghaffour and H. K. Shon, Sep. Purif. Technol., 2018, 212, 368-375.

66 F. Volpin, J. Jiang, I. E. Saliby, M. Preire and H. K. Shon, J. Cleaner Prod., 2020, 270, 122390.

67 S. Phuntsho, H. K. Shon, S. Hong, S. Lee and S. Vigneswaran, Rev. Environ. Sci. Biotechnol., 2012, 11, 147-168.

68 J. R. Mccutcheon and M. Elimelech, J. Membr. Sci., 2017, 284, 237-247.

69 T. Y. Cath, A. E. Childress and M. Elimelech, J. Membr. Sci., 2006, 281, 70-87.

70 N. T. Hancock, X. Pei, D. M. Heil, C. Bellona and T. Y. Cath, Environ. Sci. Technol., 2011, 45, 8483-8490.

71 A. Sz, A. Lz, B. Cyt and A. Dm, J. Membr. Sci., 2012, 396, 1-21.

72 H. T. Madsen, N. Bajraktari, C. Hélix-Nielsen, V. Bart and E. G. S. Gaard, J. Membr. Sci., 2015, 476, 469-474.

73 K. Lutchmiah, A. Verliefde, K. Roest, L. C. Rietveld and E. R. Cornclissen, Water Res., 2014, 58, 179-197.

74 J. Zhang, Q. She, V. Chang, C. Y. Tang and R. D. Webster, Environ. Sci. Technol., 2014, 48, 3386-3394.

75 H. Ray, F. Perreault and T. H. Boyer, Environ. Sci. Technol., 2020, 54, 11556-11565.

76 F. Volpin, L. Chekli, S. Phuntsho, J. Cho, N. Ghaffour, J. S. Vrouwenvelder and H. K. Shon, Chemosphere, 2018, 203, 482-489.

77 F. Volpin, H. Heo, M. Johir, J. Cho, S. Phuntsho and H. K. Shon, Water Res., 2019, 150, 47-55.

78 S. Engelhardt, J. Vogel, S. E. Duirk, F. B. Moore and H. A. Barton, J. Water Process. Eng., 2020, 34, 101135.

79 S. Engelhardt, K. Bender, J. Vogel, S. Duirk and H. Barton, Int. J. Speleol., 2020, 49, 229-234.

80 F. Volpin, H. Yu, J. Cho, C. Lee and H. K. Shon, J. Hazard. Mater., 2019, 378, 120724.

81 A. D. Wilt, A. Butkovskyi, K. Tuantet, L. H. Leal and G. Zeeman, J. Hazard. Mater., 2015, 304, 84-92.

82 H. Ray, F. Perreault and T. H. Boyer, Environ. Sci.: Water Res. Technol., 2019, 5, 1993-2003.

83 A. H. Galama, G. Daubaras, O. S. Burheim, H. Rijn Aa Rts and J. W. Post, J. Membr. Sci., 2014, 452, 219-228. 
84 M. Xie, H. K. Shon, S. R. Gray and M. Elimelech, Water Res., 2016, 89, 210-221.

85 H. Strathmann, Desalination, 2010, 264, 268-288.

86 J. De Paepe, R. Lindeboom, M. Vanoppen, K. De Paepe, D. Demey, W. Coessens, B. Lamaze, A. Verliefde, P. Clauwaert and S. E. Vlaeminck, Water Res., 2018, 144, 76-86.

87 W. A. Tarpeh, J. M. Barazesh, T. Y. Cath and K. L. Nelson, Environ. Sci. Technol., 2018, 52, 1453-1460.
88 Y. K. Wang, Y. K. Geng, X. R. Pan and G. P. Sheng, Chem. Eng. Sci., 2017, 171, 451-458.

89 M. Ying and C. Y. Tang, Desalination, 2018, 425, 156-174.

90 V. Federico, C. Yun, K. Hanki, F. Stefano and J. Namjo, Water Res., 2020, 186, 116320.

91 C. J. Davey, D. Azzini, A. L. Eusebi, R. Tierney, L. Williams, Y. Jiang, A. Kolios, S. Tyrrel and M. Pidou, J. Membr. Sci., 2019, 584, 343-352. 